\title{
Effects of acidity on dissolved organic carbon in organic soil extracts, pore water and surface litters
}

Article

Accepted Version

Creative Commons: Attribution-Noncommercial-No Derivative Works 4.0

Pschenyckyj, C. M., Clark, J. M., Shaw, L. J., Griffiths, R. I. and Evans, C. D. (2020) Effects of acidity on dissolved organic carbon in organic soil extracts, pore water and surface litters. Science of the Total Environment, 703. 135585. ISSN 00489697 doi: https://doi.org/10.1016/j.scitotenv.2019.135585 Available at https://centaur.reading.ac.uk/87810/

It is advisable to refer to the publisher's version if you intend to cite from the work. See Guidance on citing.

To link to this article DOI: http://dx.doi.org/10.1016/j.scitotenv.2019.135585

Publisher: Elsevier

All outputs in CentAUR are protected by Intellectual Property Rights law, including copyright law. Copyright and IPR is retained by the creators or other copyright holders. Terms and conditions for use of this material are defined in the End User Agreement.

www.reading.ac.uk/centaur 
Central Archive at the University of Reading

Reading's research outputs online 


\section{Effects of acidity on dissolved organic carbon in organic soil extracts, pore water and surface litters.}

Catharine M. Pschenyckyj ${ }^{\text {a* }}$, Joanna M. Clark ${ }^{\mathrm{b}}$, Liz J. Shaw ${ }^{\mathrm{b}}$, Robert I. Griffiths ${ }^{\mathrm{c}}$, Chris D. Evans $^{c}$

a Department of Geography and Environmental Sciences, Northumbria University, Newcastle upon Tyne, NE1 8ST, UK

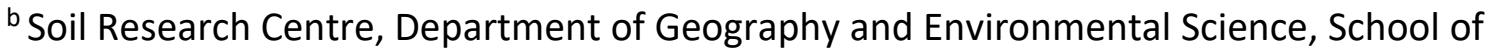
Archaeology, Geography and Environmental Science, The University of Reading, Whiteknights, PO Box 227, Reading, RG6 6AB, UK

${ }^{\mathrm{C}}$ Centre for Ecology and Hydrology, Deiniol Rd, Bangor, LL57 2UP, UK

*Correspondence: Catharine Pschenyckyj; catharine.pschenyckyj@northumbria.ac.uk

\section{Abstract}

Over the past 30-40 years, dissolved organic carbon (DOC) concentrations have increased in soil solutions and surface waters in many acid-sensitive areas of Europe and North America. This has been linked to recovery from acidification in response to decreasing levels of atmospheric pollution. Evidence from radiocarbon dating suggests that DOC in surface waters is typically derived from recently photosynthesised organic matter such as plant litter and exudates, yet there is little information on the $\mathrm{pH}$-sensitivity of organic matter solubility, or its decomposition, in litter layers and in different organic soils. Based on data collected at four established field $\mathrm{pH}$-manipulation experiments in upland areas of the United Kingdom, we examined the sources, composition and acid-sensitivity of DOC export from the litter and organic soils. We found that litter generated nearly three times more DOC than the organic soils, consistent with radiocarbon evidence that recent plant inputs are a major source of DOC export. Furthermore, litter derived DOC had lower specific ultraviolet light absorbance (SUVA) than organic soil DOC, suggesting greater biodegradability. Organic soil DOC concentrations were more strongly related to experimentally manipulated $\mathrm{pH}$, implying that the mobility of this $\mathrm{DOC}$ is subject to physicochemical rather than biotic controls. 
We conceptualise the process of DOC export from these systems as i) production of 'new' DOC through incomplete decomposition of plant material in the surface litter; ii) the remaining undecomposed litter becomes part of the organic soil, and this is subjected to further decomposition, producing less biodegradable DOC which is controlled by acidity; and iii) mobile DOC is transported to rivers via near surface flows. Our results suggest that widely observed increases in surface water DOC in areas undergoing recovery from acidification are due primarily to physicochemically mediated controls on organic matter solubility, rather than biologically mediated changes in DOC production or decomposition.

\section{Graphical Abstract}

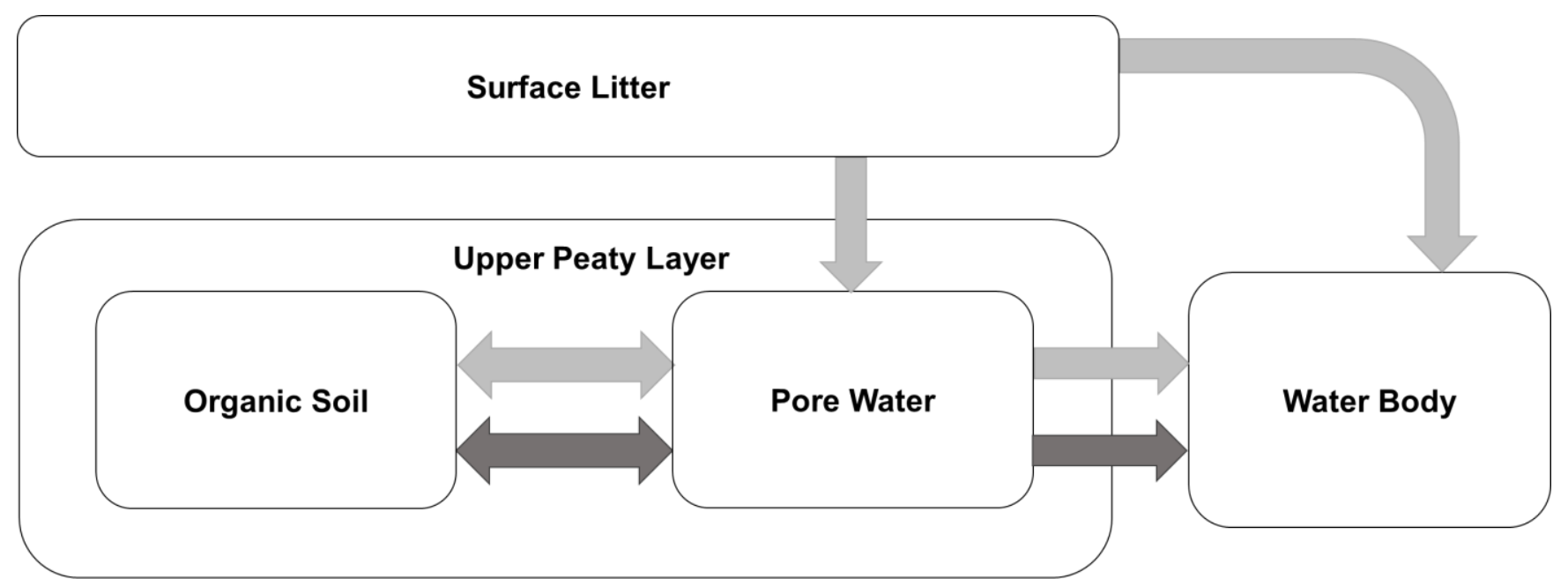

DOC 1 (Recalcitrant, humic, coloured, high SUVA, acid sensitive)

DOC 2 (Labile, non-humic, low coloured, low SUVA, less acid sensitive)

\section{Keywords}

DOC; Litter; Solubility; Acid deposition; Peat; Podzol

\subsection{Introduction}

Dissolved organic carbon (DOC) represents a major natural carbon export from peatlands and other organic rich soils (Hope et al., 1994; Billett et al., 2004; Clark et al., 2007; Dinsmore et al., 2010), and waters draining these areas have high concentrations of DOC (Aitkenhead et al., 1999; Evans et al., 2006). There has been a considerable increase in DOC concentrations in waters draining catchments dominated by organic soils in much of the industrialised Northern Hemisphere since the 1980s (Evans et al., 2005; Monteith et al., 2007; Oulehle and Hruška, 2009; Couture et al., 2012; SanClements et al., 2012b). This 
increase in DOC export from peatlands and other organic soils not only affects carbon budgets (Dinsmore et al., 2010), but also adds significantly to drinking water treatment costs and efficacy of processes (Ritson et al., 2014). In addition, greater DOC concentrations in terrestrial waters can profoundly alter the functioning of aquatic ecosystems by influencing light regime (Schindler, 1971), energy and nutrient supply (Wetzel, 1992), and the mobility of trace metals and organic pollutants (Haitzer et al., 1998; Lawlor and Tipping, 2003).

Although a wide range of mechanisms for increasing DOC trends have been proposed, a growing body of research suggests that it represents a response to recovery from acidification, as reducing levels of acidity and ionic strength within soils permit a greater proportion of organic matter to remain in solution, and thus available for leaching to surface waters. This mechanism is supported by a range of long-term data analyses (Evans et al., 2006; de Wit et al., 2007; Monteith et al., 2007; Daniels et al., 2008; Oulehle and Hruška, 2009; Oulehle et al., 2011; SanClements et al., 2012a; Oulehle et al., 2017); laboratory experiments (Clark et al., 2011; Palmer et al., 2013); field experiments (Evans et al., 2008; Ekström et al., 2011; Evans et al., 2012; Moldan et al., 2012; Oulehle et al., 2013); and palaeolimnological reconstructions (Bragee et al., 2015).

The significance of increased DOC export for the terrestrial carbon balance is a matter of debate. With peatlands being a major store of carbon (Gorham, 1991), and with drastic changes in DOC export from these ecosystems, concerns have been raised over the future of peatland carbon balances (Freeman et al., 2001). Radiocarbon $\left({ }^{14} \mathrm{C}\right)$ measurements of DOC in rivers draining peaty catchments that have not been disturbed by intensive land-use activities consistently show that this DOC is of relatively recent origin, i.e. that it is comprised of material that was photosynthesised from the atmosphere within the last few decades, and in some cases the last few years (Palmer et al., 2001; Billett et al., 2006; Evans et al., 2007; Raymond et al., 2007; Clark et al., 2008; Tipping et al., 2010). This observation is inconsistent with the concept of large-scale destabilisation of soil organic carbon, and instead suggests that DOC exports must derive from living plant material (e.g. root exudates), recently senesced plant material (partially decomposed litter), or from the nearsurface of organic soils. In soils that have been more disturbed by land-use activities, on the other hand, DOC tends to have an older ${ }^{14} \mathrm{C}$ signature, indicating that elevated DOC losses in 
these systems could be indicative of soil carbon destabilisation (Butman et al., 2013; Evans et al., 2014).

Finally, there remains a lack of information regarding the controls on DOC export from different soil types. While peats generally represent the largest DOC source per unit area (Aitkenhead et al., 1999), other spatially extensive soil types with carbon-rich surface horizons may also act as important DOC sources to surface waters, especially during high flow periods (Hood et al., 2006; Raymond and Saiers, 2010). Whilst much of the literature focuses on DOC exported from peatland areas, the role of organo-mineral soils in this context has received less attention, despite marked differences in their structure, chemical composition and hydrological properties.

The key aims of this study were therefore to improve understanding of: i) the relative contribution of litter and near surface organic soil to DOC production in terms of quantity and quality and how this varies between peat and organo-mineral soils; and ii) the extent to which changes in soil pH have modified the amount and/or composition of DOC released.

\subsection{Methods}

\subsection{Site Description and Experimental Design}

For this study we used an existing set of four long-term acid manipulation field experiments, situated in two unforested upland (moorland) locations in the UK with contrasting historic rates of acid deposition, and therefore present-day soil acidity (Evans et al., 2012). At each site, replicated acidity manipulations were established within two soil types; blanket peats (histosol) and peaty podzols (histic podzol) (FAO, 2014). These soil types are among the commonest soils present in the UK uplands, and they also occur extensively in other cool, humid temperate regions. Previous work by Evans et al (2012) focused only on pore water dynamics, here we build on this work to study the litter and soil layers separately.

The first study site, the Migneint $\left(3^{\circ} 48.8^{\prime} \mathrm{W}, 52^{\circ} 59.6^{\prime} \mathrm{N}, 460 \mathrm{~m}\right.$ a.s.I.), is a relatively undisturbed area of predominantly blanket peatland in North Wales, with areas of organomineral soil on steeper slopes and hilltops. The area has historically low levels of atmospheric sulphur and nitrogen pollution. Peaknaze $\left(1^{\circ} 54.5^{\prime} \mathrm{W}, 53^{\circ} 28.3^{\prime} \mathrm{N}, 440 \mathrm{~m}\right.$ a.s.l.), in Northern England, is a more disturbed region affected by relatively intensive land 
management and historically high levels of atmospheric pollution, which has led to degradation of the ecosystem including Sphagnum loss and erosion (Tallis, 1985).

\subsection{Field Experimental Operation}

The experimental sites were established in August 2007, and consist of twelve $9 \mathrm{~m}^{2}$ plots at each of the four experimental sites (termed Migneint Peat, Migneint Podzol, Peaknaze Peat, Peaknaze Podzol). Each comprises a randomised blocked design with four replicates of control, acid and alkaline treatments. Treatments were applied initially from October 2008 until December 2012 (Evans et al., 2012), and then re-established for the purposes of this study (using the same methods, treatments and plot allocations) from January 2015 until October 2016. Acid plots received a monthly dose of sulphuric acid $\left(\mathrm{H}_{2} \mathrm{SO}_{4}\right)$ mixed with rainwater (20 I) collected at the site. The concentration applied was $50 \mathrm{~kg} \mathrm{~S} \mathrm{ha}^{-1} \mathrm{yr}^{-1}$ at the podzol sites and $100 \mathrm{~kg} \mathrm{~S} \mathrm{ha}^{-1} \mathrm{yr}^{-1}$ at the peat sites, this concentration being similar to the ambient sulphur deposition in the Peak District in the 1970s. A higher dose was applied to peat plots to achieve a similar $\mathrm{pH}$ change after taking account of the buffering effects of sulphate reduction. A 10 I rinse of rainwater followed to ensure the treatment infiltrated into the soil and to minimise any direct toxicity effects on plant foliage.

The same procedure was followed for the alkaline plots with sodium hydroxide $(\mathrm{NaOH})$ and potassium hydroxide $(\mathrm{KOH})$, followed by a rinse containing Magnesium Chloride $\left(\mathrm{MgCl}_{2}\right)$ and Calcium Chloride $\left(\mathrm{CaCl}_{2}\right)$ to maintain base cation ratios similar to those observed in rainfall. The molar $\mathrm{OH}^{-}$concentration in the alkaline treatments was intended to be comparable to the $\mathrm{H}^{+}$concentration in the acid treatments. Control plots received $20 \mathrm{I}$ of rainwater only.

\subsection{Sampling}

In order to assess the quantity and quality of DOC mobile in the surface litter and soil layers, samples were collected and chemical analysis was performed on cold water extracts. Soil pore water samples represent direct measurements of DOC which is mobile and could potentially leach to terrestrial water bodies.

We collected monthly pore water samples from September 2015 until October 2016, approximately one week after treatments were applied. Samples were collected from a depth of $10 \mathrm{~cm}$ below the surface using syringes and Rhizon suction samplers (part number 
19.21.35, www.rhizosphere.com), from four locations within each plot. These were then bulked into one sample per plot following the protocol described by Evans et al. (2012). Litter was collected directly from the soil surface. A soil sample was taken from this position by cutting a square 'flap' of approximately $10 \mathrm{~cm}^{2}$ through the vegetation, and removing the required quantity of organic soil ( $\sim 30 \mathrm{~g}$ ) from a depth of $10-20 \mathrm{~cm}$. The flap was then put back in place and lightly pressed down, in order to minimise disturbance to the plot. Four litter and peat samples were taken from each plot, $10-15 \mathrm{~cm}$ in from the edge to avoid areas impacted by compaction. We collected samples at three time points during the 2016 growing season (April, July and October) and stored these at $4{ }^{\circ} \mathrm{C}$ in plastic re-sealable bags.

\subsection{Laboratory Analysis}

Organic soil and litter samples were processed in the lab by cutting and/or chopping into 1 $2 \mathrm{~cm}$ pieces and homogenising. Unwanted material such as stones, invertebrates, thick roots and living plant material was removed. Using $4 \mathrm{~g}$ of sample and ultrapure (MilliQ 18.2 $\mathrm{M} \Omega$ ) water, samples underwent a cold water extraction on a horizontal shaker (30 rpm) at room temperature for 3 hours for organic soil (1:10 mass to volume ratio) and 24 hours for litter (1:20 mass to volume ratio). Samples were then centrifuged ( $3500 \mathrm{rpm}$ for 20 minutes) and vacuum filtered through $0.45 \mu \mathrm{m}$ cellulose membrane filter paper. This extraction method was adapted from Ghani et al. (2003).

We analysed extracts and pore water samples for $\mathrm{pH}$, electrical conductivity, total organic carbon, and ultraviolet absorbance. A Thermalox TC-TN analyser (Analytical Sciences, Ltd., UK) was used to measure the concentration of DOC, by subtracting the amount of total inorganic carbon (TIC) from the amount of total carbon (TC). Pore water DOC concentrations were expressed in $\mathrm{mg} \mathrm{I}^{-1}$ as these samples were direct measures of DOC concentrations in situ. However, DOC concentration in organic soil and litter extracts were expressed in terms of mg DOC extracted per g of dry material (Pschenyckyj, 2018), as is standard practice for this measure (Don and Kalbitz, 2005).

We used optical measures to define spectroscopic properties as a proxy measure of DOC quality. Samples were diluted to less than 1 absorbance unit (AU), as determined by measuring absorbance at $240 \mathrm{~nm}$. UV visible absorbance spectra were determined using UV transparent 96 well plates on a Spectromax M2e Microplate Reader (Molecular Devices, San 
Jose, $C A$ ) set to scan at wavelengths between 240 and $600 \mathrm{~nm}$ with a $1 \mathrm{~nm}$ increment. As absorbance data obtained by the microplate method is slightly lower than the cuvette method (due to the difference in absorbance between plastic and quartz), we multiplied data by bespoke correction factor developed through calibration data generated in the lab (Tim Jones, pers comm) (Pschenyckyj, 2018). Specific ultraviolet absorbance at $254 \mathrm{~nm}$ (SUVA 254 , calculated by converting the pathlength to $m$ (multiplying by 100) and dividing absorbance value at $254 \mathrm{~nm}$ corrected for a pathlength of $1 \mathrm{~m}$ by the DOC concentration in $\mathrm{mg}^{-1}$ ) has been identified as a proxy for the aromatic and hydrophobic fractions, and molecular weight of dissolved organic matter (DOM) (Weishaar et al., 2003; Spencer et al., 2012; Chowdhury, 2013).

\subsection{Data Analysis}

We analysed data using the R statistical package (RDevelopment Core Team, 2008). We assessed whether data met the assumptions of Analysis of Variance (ANOVA), including normality and equal variance, and transformations were applied where necessary (Supplementary Table S2). ANOVA was used to examine the effect of various factors and their interactions on sample chemical properties of $\mathrm{pH}, \mathrm{DOC}$ concentration and $\mathrm{SUVA}_{254}$. When significance was apparent, post hoc tests using the 'Tukey HSD' function in R were used to confirm where significant differences occurred between groups. In addition, we used Spearman's Rank Correlation Coefficient to assess the significance, direction and strength of relationships between $\mathrm{pH}$ and $\mathrm{DOC}$ concentration.

\subsection{Results}

\subsection{The relative contribution of litter and near surface organic matter to DOC production}

Significantly more DOC was extracted from litter than from organic soil during April $(P=$ $<0.001)$, July $(p=<0.001)$ and October $(p=<0.001$; Figure $1 a)$, irrespective of soil type or location. Over the full set of measurements, mean litter extract DOC was around $2.8 \mathrm{mg} \mathrm{g}^{-1}$ (with DOC concentration values across all control plots and sampling times ranging from 1.2 $\mathrm{mg} \mathrm{g}^{-1}$ minimum to $6.5 \mathrm{mg} \mathrm{g}^{-1}$ maximum) compared to $1 \mathrm{mg} \mathrm{g}^{-1}$ in organic soil extracts (concentration range $0.4-2.6 \mathrm{mg} \mathrm{g}^{-1}$ ). Mean extract DOC increased from $2.4 \mathrm{mg} \mathrm{g}^{-1}$ during spring to $3.2 \mathrm{mg} \mathrm{g}^{-1}$ during autumn for litter $(p=0.039)$ but remained fairly constant in organic soil extracts. 
Based on SUVA $_{254}$ analysis, DOM extracted from organic soil samples was significantly more aromatic than DOM extracted from litter samples (mean values for all samples are 2.8 (concentration range $0.7-6.5$ ) and 2.4 (concentration range $0.5-6.1$ ) I $\mathrm{mg} \mathrm{C}^{-1} \mathrm{~m}^{-1}$ respectively). Organic soil extract SUVA 254 was significantly $(p=<0.05)$ lower in October than at other times, whereas in litter extracts it remained fairly uniform at $2.3-2.6 \mathrm{I} \mathrm{mg} \mathrm{C^{-1 }}$ $\mathrm{m}^{-1}$ (Figure $1 b$ ).

a)

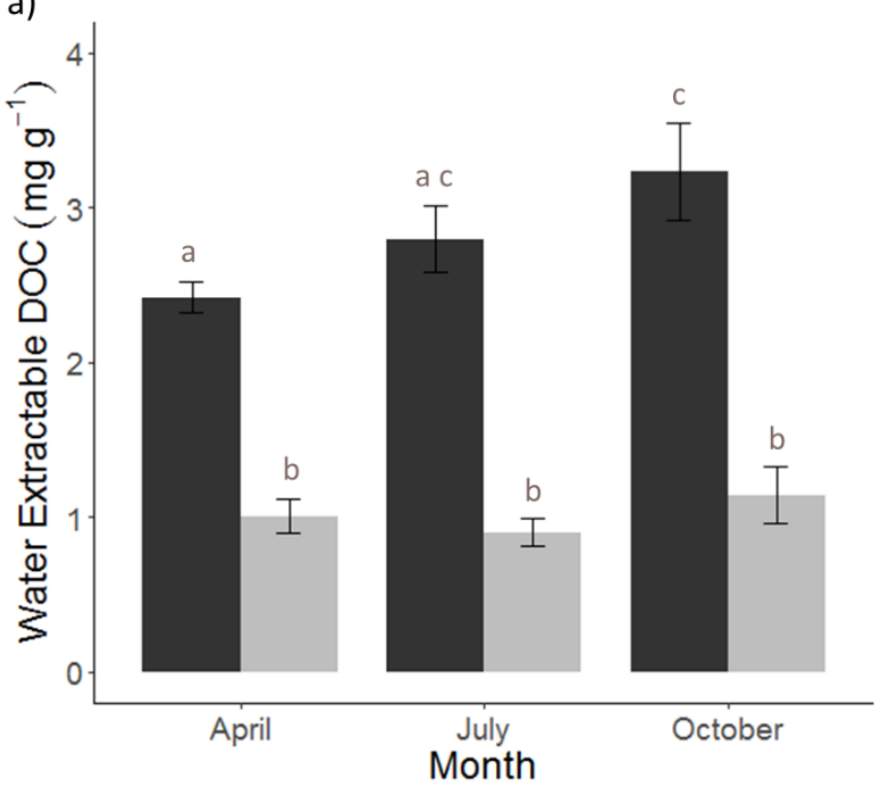

b)

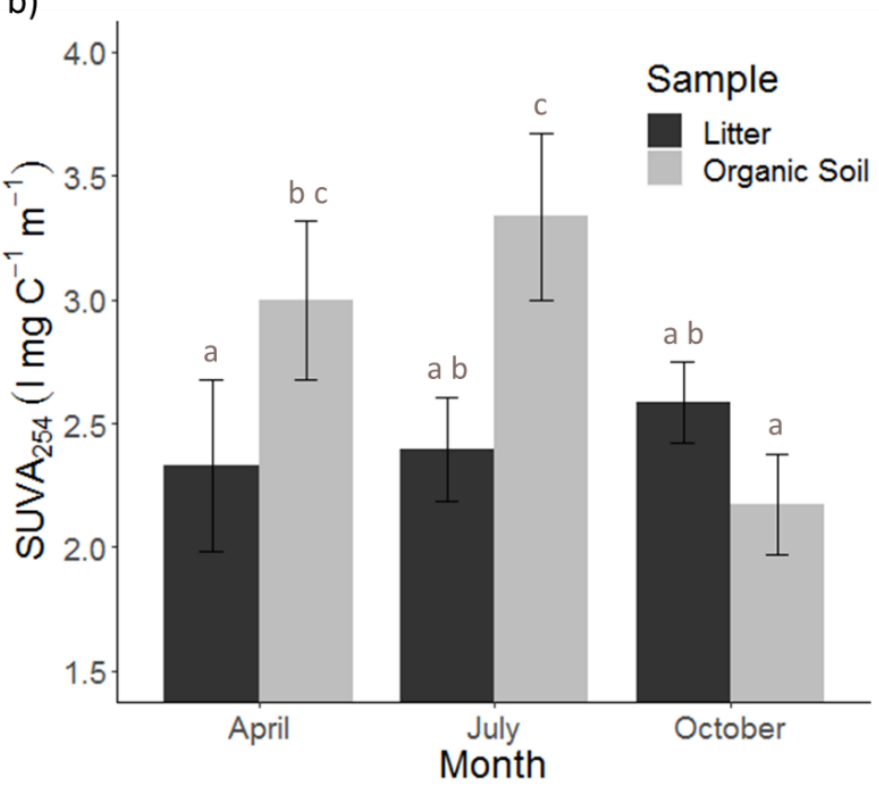

Figure 1: a) DOC, and b) SUVA 254 from extracts of organic soil and surface litter samples. Data are bulked for all control plots during April, July and October 2016. Letters indicate significant differences. Error bars show standard errors.

Based on a correlation analysis, there was no relationship between litter, and organic soil DOC extracts $(p=0.114)$ and pore water DOC $(p=0.376)$ indicating little connection between these two DOC sources in terms of production amounts. However, the SUVA 254 in surface litter did correlate with that in organic soil $(p=0.005$, Rho $=0.407)$ indicating an association between the quality of DOC produced. A significant positive relationship between SUVA 254 in pore water and in extracts from the organic soil $(p=0.002$, Rho $=0.446$; Table 1) was found, indicating a good association between pore water extracts and water extractable carbon from organic soil. By contrast, the SUVA 254 in surface litter was found not to correlate with that in pore water $(p=0.106)$, indicating poor correlation between litter extracts and direct measures of pore water. 
Table 1: Results of correlation analysis comparing data (DOC and SUVA 254 ) between different sample types. $p$ values are bold where significant at $<0.05$, whilst Spearman's Rho values are in italics.

\begin{tabular}{|c|c|c|c|}
\hline & & Litter & Organic Soil \\
\hline \multirow{2}{*}{ Organic Soil } & DOC & $\begin{array}{c}0.114 \\
-0.234\end{array}$ & \\
\hline & SUVA & $\begin{array}{l}\mathbf{0 . 0 0 5} \\
0.407 \\
\end{array}$ & \\
\hline \multirow{2}{*}{ Pore Water } & DOC & $\begin{array}{l}0.376 \\
0.131\end{array}$ & $\begin{array}{c}0.442 \\
-0.099\end{array}$ \\
\hline & SUVA & $\begin{array}{l}0.106 \\
0.241\end{array}$ & $\begin{array}{l}\mathbf{0 . 0 0 2} \\
0.446\end{array}$ \\
\hline
\end{tabular}

\subsection{Influence of soil type on DOC quantity and quality from different sources}

When assessing how DOC varies between peat and podzol soil, more DOC was extracted from podzol litter $\left(3.41 \mathrm{mg} \mathrm{g}^{-1}\right)$ than from peat litter $\left(2.46 \mathrm{mg} \mathrm{g}^{-1}\right)$ (this only being significant at Migneint $p=<0.001$; Figure 2a), but for the organic soil layer, we found that more DOC was extracted from peat than podzol soil $\left(1.65\right.$ and $0.94 \mathrm{mg} \mathrm{g}^{-1}$ for Migneint Peat and Podzol, $\mathrm{p}<0.001 ; 0.97$ and $0.52 \mathrm{mg} \mathrm{g}^{-1}$ for Peaknaze Peat and Podzol, $\mathrm{p}<0.001$; Figure 2c). Also, DOM extracted from both litter (Migneint $p=<0.001$ ) and organic soil (Migneint $p=$ $<0.001$; Peaknaze $p=0.013$ ) had a significantly higher SUVA 254 value when obtained from podzol than from peat (Figures $2 b \& 2 d$ ).

When assessing direct measurements of DOC concentration in pore water, Peaknaze Peat had considerably more DOC ( $80 \mathrm{mg} \mathrm{l}^{-1}$, compared to just 24 - $34 \mathrm{mg} \mathrm{l}^{-1}$ at other sites) (Figure 2e) which also had a higher SUVA 254 value $\left(4.4 \mathrm{I} \mathrm{mg} \mathrm{C}^{-1} \mathrm{~m}^{-1}\right.$ compared to $3.7 \mathrm{I} \mathrm{mg} \mathrm{C}^{-1} \mathrm{~m}^{-1}$ at other sites), when compared to other sites (although statistically this was only significantly different to Migneint Peat) (Figure 2f). Therefore, apart from this site, there was no difference in pore water DOC quantity and quality between soil types. 


\section{Litter Extracts}

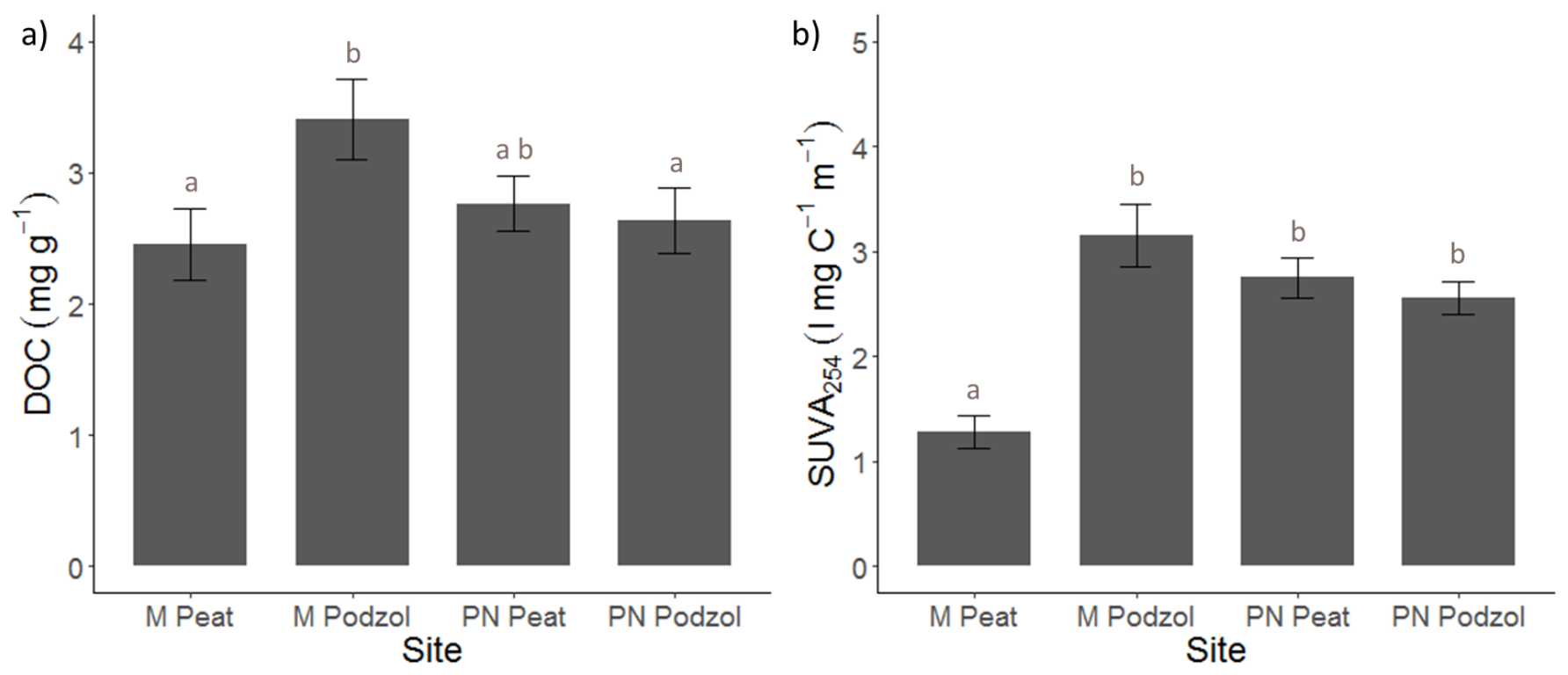

Organic Soil Extracts
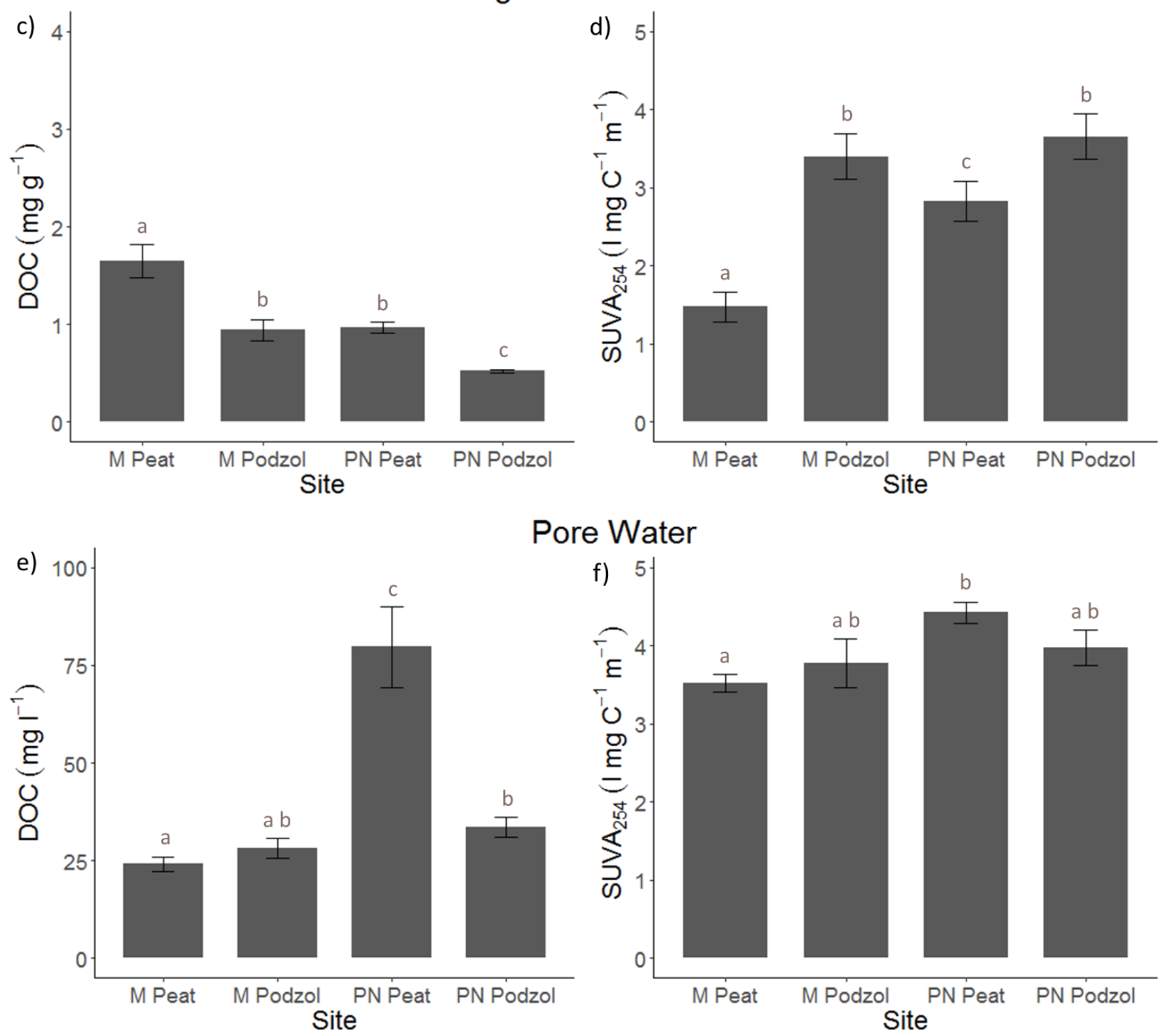
Figure 2: DOC and SUVA 254 of extracts from surface litter $(a, b)$ and organic soil (c, d), and direct measurements of DOC concentration in pore water (e, f). Samples were collected from control plots only during April, July and October 2016. ' $M$ ' refers to Migneint and 'PN' refers to Peaknaze. Letters signify where significant differences occurred. Error bars show standard errors.

\subsection{Effect of acidity on DOC}

As expected the Peaknaze experimental sites were more acidic (mean pore water $\mathrm{pH}$ of 3.98 units at peat control plots and 4.10 units at podzol control plots), while both Migneint sites had a control plot $\mathrm{pH}$ of $\sim 4.30$ units (Figure $3 \mathrm{e}$ ). We observed clear effects of acidity manipulation on the $\mathrm{pH}$ of litter extracts, organic soil extracts and pore waters (Figure 3 a,c,e). Mean litter extract $\mathrm{pH}$ across all experimental sites was 5.28 units for the acid treatment, and 6.10 units for the alkaline treatment. For organic soil extracts the difference in mean $\mathrm{pH}$ values between acidity treatments was narrower (4.74 units for acid and 5.22 units for alkaline). Mean pore water $\mathrm{pH}$ was 3.98 units in the acid treatments, and 4.52 units in the alkaline treatments. Although not always statistically significant, differences in $\mathrm{pH}$ between acidity treatments were consistent for all experimental sites and for all measurement types (Figure 3a, c, e). In general, differences were larger and statistically significant for the two Peaknaze sites and for the Migneint podzol site, and smaller/nonsignificant at the Migneint peat site. 


\section{Litter}
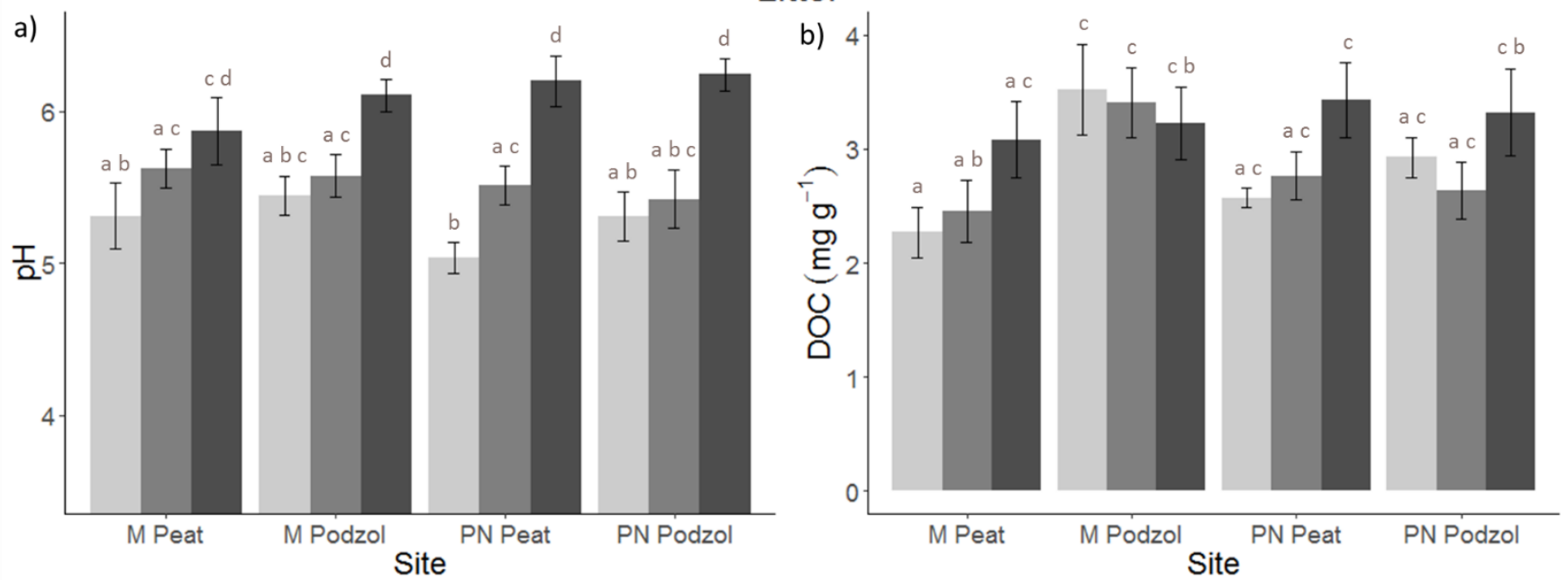

Organic Soil
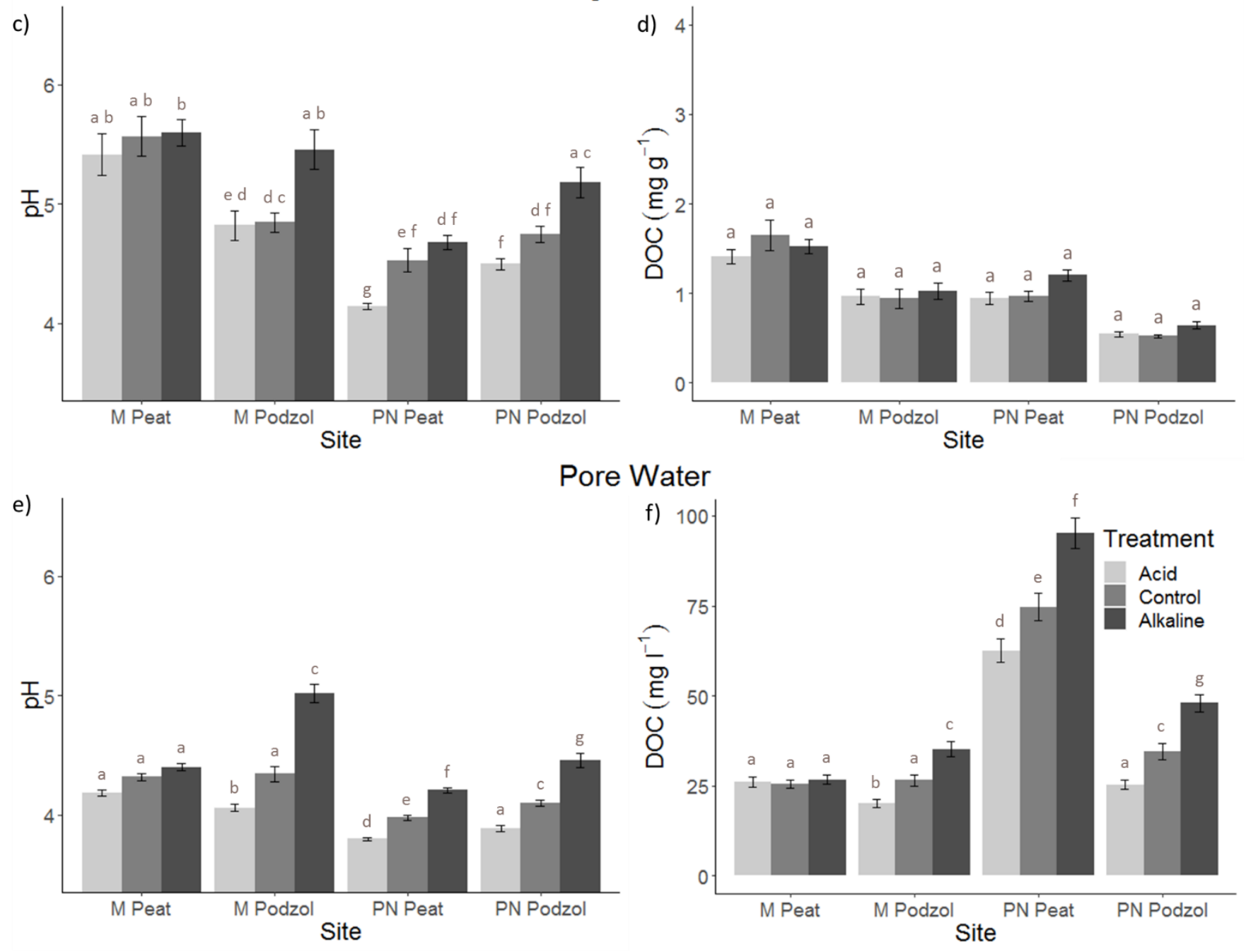

Figure 3: Mean pH and DOC of surface litter (a, b) and organic soil (c, d) extracts, and pore water samples (e, f). Samples for extracts were collected during April, July and October 2016, whilst pore water samples were collected over a 13 months period, and data is bulked for these months. ' $M$ ' refers to Migneint and 'PN' refers to Peaknaze. Letters signify where significant differences occur. Error bars show standard errors. 
The concentration of DOC in peat surface litter extracts corresponded to the acidity treatments applied, with an average DOC of $5.17 \mathrm{mg} \mathrm{g}^{-1}$ for acid plots compared to $6.03 \mathrm{mg}$ $\mathrm{g}^{-1}$ for alkaline plots, but these differences were not significant at $\mathrm{p}<0.05$ (Figure 3b). Litter extract DOC from the podzol plots was not related to the acidity manipulations. We also found no significant correlation between litter extract $\mathrm{pH}$ and $\mathrm{DOC}$ across all samples $(\mathrm{p}=$ 0.411; Figure 4a). Acidity treatments also had no significant effect on SUVA254 in litter extracts $(p=0.073 ;$ Table 2$)$.
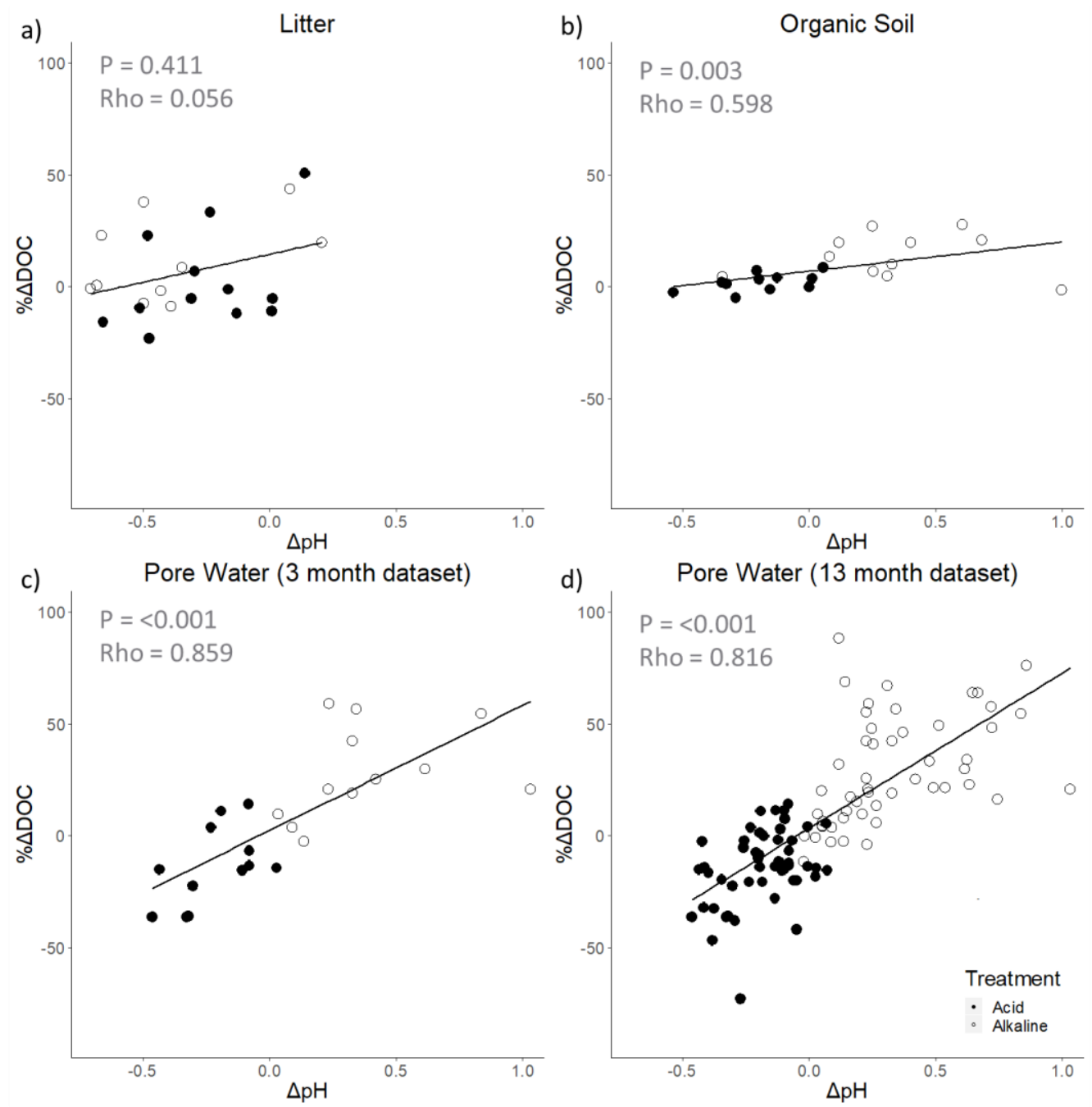

Figure 4: Scatterplots comparing mean change in $\mathrm{pH}$ and percentage DOC for acid and alkaline treatments compared to the control, for each of the four experimental sites and sampling months, for surface litter (a) and organic soil (b) extracts, and pore water samples with three (c) and thirteen (d) month datasets. Significance (p value) and strength of relationship (Rho value) were obtained using Spearman's Rank. 
Organic soil extract DOC also showed no relationship to the acidity treatments applied (Figure 3d), and treatment effect was found not to depend on site location or soil type $(p=$ 0.296). However, when assessed further through a correlation analysis, we found that there was a significant positive relationship between extract $\mathrm{DOC}$ and $\mathrm{pH}$ for individual samples (Figure 4b). Again we found no effect of acidity treatments on SUVA 254 for organic soil extracts $(p=0.591 ;$ Table 2$)$.

Table 2: Mean SUVA254 of DOM $\left(\mathrm{mg} \mathrm{C}^{-1} \mathrm{~m}^{-1}\right)$ in litter and organic soil extracts, and pore water samples, with standard error values in italics. Significant differences (at $p=<0.05$ ) obtained using a post hoc analysis on ANOVA tests are summarised in the 'Significant Differences' column, where ' $=$ ' represents no significance.

\begin{tabular}{|c|c|c|c|c|c|}
\hline Sample & Site & Acid & Control & Alkaline & Significant Differences \\
\hline \multirow{8}{*}{ Litter } & \multirow{2}{*}{ Migneint Peat } & 1.50 & 1.28 & 2.14 & \multirow{2}{*}{ Acid=Control=Alkaline } \\
\hline & & 0.16 & 0.16 & 0.43 & \\
\hline & \multirow{2}{*}{ Migneint Podzol } & 2.63 & 3.15 & 2.78 & \multirow{2}{*}{ Acid=Control=Alkaline } \\
\hline & & 0.12 & 0.30 & 0.10 & \\
\hline & \multirow{2}{*}{ Peaknaze Peat } & 2.37 & 2.75 & 2.59 & \multirow{2}{*}{ Acid=Control=Alkaline } \\
\hline & & 0.12 & 0.19 & 0.16 & \\
\hline & \multirow{2}{*}{ Peaknaze Podzol } & 2.66 & 2.56 & 2.95 & \multirow{2}{*}{ Acid=Control=Alkaline } \\
\hline & & 0.43 & 0.15 & 0.26 & \\
\hline \multirow{8}{*}{ Organic Soil } & \multirow{2}{*}{ Migneint Peat } & 1.73 & 1.64 & 1.66 & \multirow{2}{*}{ Acid=Control=Alkaline } \\
\hline & & 0.15 & 0.19 & 0.13 & \\
\hline & \multirow{2}{*}{ Migneint Podzol } & 3.45 & 3.54 & 3.43 & \multirow{2}{*}{ Acid=Control=Alkaline } \\
\hline & & 0.29 & 0.23 & 0.30 & \\
\hline & \multirow{2}{*}{ Peaknaze Peat } & 2.77 & 2.99 & 2.76 & \multirow{2}{*}{ Acid=Control=Alkaline } \\
\hline & & 0.15 & 0.21 & 0.18 & \\
\hline & \multirow{2}{*}{ Peaknaze Podzol } & 4.04 & 3.62 & 3.94 & \multirow{2}{*}{ Acid=Control=Alkaline } \\
\hline & & 023 & 0.22 & 0.31 & \\
\hline \multirow{8}{*}{ Pore Water } & \multirow[b]{2}{*}{ Migneint Peat } & 3.66 & 3.65 & 3.72 & \multirow[b]{2}{*}{ Acid=Control=Alkaline } \\
\hline & & 0.06 & 0.08 & 0.07 & \\
\hline & \multirow{2}{*}{ Migneint Podzol } & 3.33 & 3.72 & 3.90 & \multirow{2}{*}{ Acid $<$ Control=Alkaline } \\
\hline & & 0.12 & 0.13 & 0.09 & \\
\hline & \multirow{2}{*}{ Peaknaze Peat } & 4.33 & 4.39 & 4.60 & \multirow{2}{*}{ Acid=Control=Alkaline } \\
\hline & & 0.09 & 0.08 & 0.12 & \\
\hline & \multirow{2}{*}{ Peaknaze Podzol } & 3.45 & 3.69 & 4.25 & \multirow{2}{*}{ Acid=Control<Alkaline } \\
\hline & & 0.12 & 0.12 & 0.13 & \\
\hline
\end{tabular}


In contrast to the litter and soil extracts, pore water DOC concentrations were strongly affected by acidity manipulation. This was evident for all sites except Migneint Peat (Figure $3 e)$, and was consistent throughout the thirteen month experimental period (Supplementary Figure S1). If we exclude the Migneint Peat, where acidity treatments did not significantly alter pore water $\mathrm{pH}$, the acid treatments reduced pore water $\mathrm{DOC}$ concentrations by 7-12 $\mathrm{mg} \mathrm{l}^{-1}$, whereas alkaline treatments increased DOC by 9-21 $\mathrm{mg} \mathrm{I}^{-1}$ (mean of thirteen month dataset, per experimental site and treatment). For all pore water samples collected from all sites over the 13 month period, we observed a strong positive correlation between the change in $\mathrm{pH}$ and DOC concentration (Rho $=0.816, \mathrm{p}<0.001$; Figure 4d). Such a correlation is also apparent for the three month period in which other organic soil and litter samples were assessed (Figure 4c). The response of pore water SUVA ${ }_{254}$ to acidity treatments was dependent on month $(p=0.014)$; in summer-autumn, SUVA $_{254}$ was generally lower in the acid treatments, and higher in the alkaline treatments, but in the preceding winter-spring period no acidity treatment effect was observed (Supplementary Figure S2). At podzol sites, alkaline treatments typically resulted in a greater SUVA $_{254}$ (mean of 3.90 and $3.45 \mathrm{I} \mathrm{mg} \mathrm{C}^{-1} \mathrm{~m}^{-1}$ at Migneint and Peaknaze), whilst acid treatments resulted in lower values (3.90 and $4.25 \mathrm{I} \mathrm{mg} \mathrm{C}^{-1} \mathrm{~m}^{-1}$; Table 2). However, statistically significant differences were only observed between control and acid plots at Migneint Podzol, and control and alkaline plots at Peaknaze Podzol. Acidity had no effect on the SUVA 254 of pore water DOM from peat sites.

\subsection{Discussion}

\subsection{DOC production from surface litter and organic soils}

Surface litter produced around three times more DOC per unit dry mass of substrate compared to organic soil, regardless of sampling month. Notwithstanding the greater mass of organic soil compared to litter, this suggests that litter is an important source of DOC production in these systems. The increase in litter extract DOC from $2.4 \mathrm{mg} \mathrm{g}^{-1}$ in April to 3.2 $\mathrm{mg} \mathrm{g}^{-1}$ in October is consistent with a seasonal biotic control on litter degradability through the year, with senescence of plant material during autumn providing a source of labile organic material and consequently greater DOC production (Clark et al., 2010). Similar values of extract DOC are reported in the literature for the species which contribute to the litter at these sites, such as Calluna $\left(\sim 6 \mathrm{mg} \mathrm{g}^{-1}\right)$, Eriophorum $\left(1-27 \mathrm{mg} \mathrm{g}^{-1}\right)$ and Sphagnum (2 
$-3 \mathrm{mg} \mathrm{g}^{-1}$ ), as well as peat extracts ( $1 \mathrm{mg} \mathrm{g}^{-1}$ ) (Ritson et al., 2016; Mastný et al., 2018). Few studies are available that compare the effect of seasonality on extractable DOC from both organic soil and litter, although work is consistent on pore waters.

DOM released from organic soil was more aromatic, as indicated by SUVA ${ }_{254}$, during April and July at $>3 \mathrm{I} \mathrm{mg} \mathrm{C}^{-1} \mathrm{~m}^{-1}$ compared to $\sim 2.3 \mathrm{I} \mathrm{mg} \mathrm{C}^{-1} \mathrm{~m}^{-1}$ in litter. Ritson et al. (2017) also observed a higher SUVA 254 value for peat compared to Calluna litter based on samples collected in May. This is attributable to the build-up of more humified material in peat due to progressive microbial degradation processes, which will preferentially remove or modify labile material in freshly senesced litter, leaving more recalcitrant aromatic material to accumulate (Kalbitz et al., 2003; McDowell et al., 2006; Saadi et al., 2006).

\subsection{To what extent have changes in soil pH modified the amount and composition of DOC released from organic catchments?}

Firstly, it is apparent that acidity treatments were successful in altering the $\mathrm{pH}$ of pore water over the 13 month experimental period. Treatments generated a $\mathrm{pH}$ range of at least $0.2 \mathrm{pH}$ units to a maximum of 0.9 units (when comparing means for acid and alkaline plots at each site). This is comparable to the increase in $\mathrm{pH}$ observed in the Countryside Survey broad habitats between 1978 and 2007 (Evans et al., 2012). There was a strong and significant relationship between change in pore water $\mathrm{pH}$ and change in $\mathrm{DOC}$ concentration, suggesting that pore water DOC concentrations are consistently sensitive to changes in acidity. The results from this experiment are similar to that of a previous acidity manipulation experiment at these sites (Evans et al., 2012), showing reproducibility and further supporting the hypothesis that increased DOC concentrations in surface waters are due to increased organic matter solubility following recovery from acidification. This change in solubility of DOC in soil solution is related to the degree of dissociation of organic acids (Oulehle et al., 2013) and is simultaneously related to changes in ionic strength (Clark et al., 2005).

The absence of a similar relationship with $\mathrm{pH}$ in litter extracts (as a key source of DOC) suggest that the effects of acidity on DOC leaching are unlikely to be biologically mediated, in contrast to the observations of Kang et al. (2018), whilst the strong relationship between changes in pore water acidity and DOC suggest a physio-chemical driver may be the cause of 
the increasing DOC trend in many acid sensitive surface waters. This builds on the findings of Evans et al (2012) that looked only at pore water data and was not able to isolate the dynamics within the litter layer. The absence of comparably strong relationships with $\mathrm{pH}$ in the organic soil extracts, compared to pore water samples collected from the same horizon, may reflect the relative level of disturbance involved, with the former method extracting a greater proportion of relatively immobile DOM from smaller pores whilst also diluting DOM and ions present, and the latter method extracting only that DOM which is mobile at any given level of acidity and at the concentration within soil pores.

DOC in both peat and podzol soil pore water responded to acid and alkaline treatments at Peaknaze, whilst only the podzol soil responded at the Migneint site (although $\mathrm{pH}$ at the Migneint peat site did not significantly change due to acidity treatment). The greatest $\mathrm{pH}$ increase with the alkaline treatment was achieved at this site of $0.68 \mathrm{pH}$ units, yet only an increase of $9 \mathrm{mg} \mathrm{l}^{-1}$ of DOC was achieved in pore water. Migneint had a higher baseline $\mathrm{pH}$ of 4.3 units compared to $\sim 4$ units at Peaknaze, and yet despite the large $\mathrm{pH}$ increase at this site, there was only a marginal increase in DOC suggesting that there is a $\mathrm{pH}$ threshold at which solubility controls DOC concentration. Such a trend which was also observed by Evans et al. (2012), who suggested that this shift from 'solubility control' to 'supply control' on DOC leaching could have implications on the future of DOC release from peatlands, as sensitivity to processes influencing DOC production increase, such as climate change and land management. For instance, DOC release from organo-mineral soils (Christ and David, 1996) and peat (Freeman et al., 2004; Clark et al., 2009) have been shown to increase with increased temperature. Climate or land-management induced changes in vegetation cover may also lead to increased DOC production with changes in climate, particularly for Calluna (Ritson et al., 2014).

The coloured aromatic fraction of DOC, which is estimated to make up $50-75 \%$ of total DOC in surface waters (Tipping et al., 1988; Grieve, 1990; Worrall et al., 2003; Hongve et al., 2004) has been shown to be sensitive to acidity (Clark et al., 2011; SanClements et al., 2012a). On this basis, we would expect low-SUVA 254 litter extract DOC to be less affected by $\mathrm{pH}$ manipulation than high-SUVA 254 organic soil extract DOC, particularly during April and July when SUVA 254 was highest. This interpretation does appear consistent with the 
correlation analysis of DOC versus $\mathrm{pH}$ shown in Figure 4 , but is not evidence in the comparisons between peat and podzols in ANOVA analysis (Figure 3).

The observed relationships in DOM quantity and quality between different components of the upper soil, and with $\mathrm{pH}$, provide some insights into the production, movement and control of DOM within organic soils. Positive relationships of SUVA ${ }_{254}$ between surface litter and organic soil extracts, and between organic soil extracts and pore water, suggest a process by which DOM is produced in the litter layer and either directly or via the organic soil layer into surface waters. A theoretical pathway model based on these relationships is shown in Figure 5.

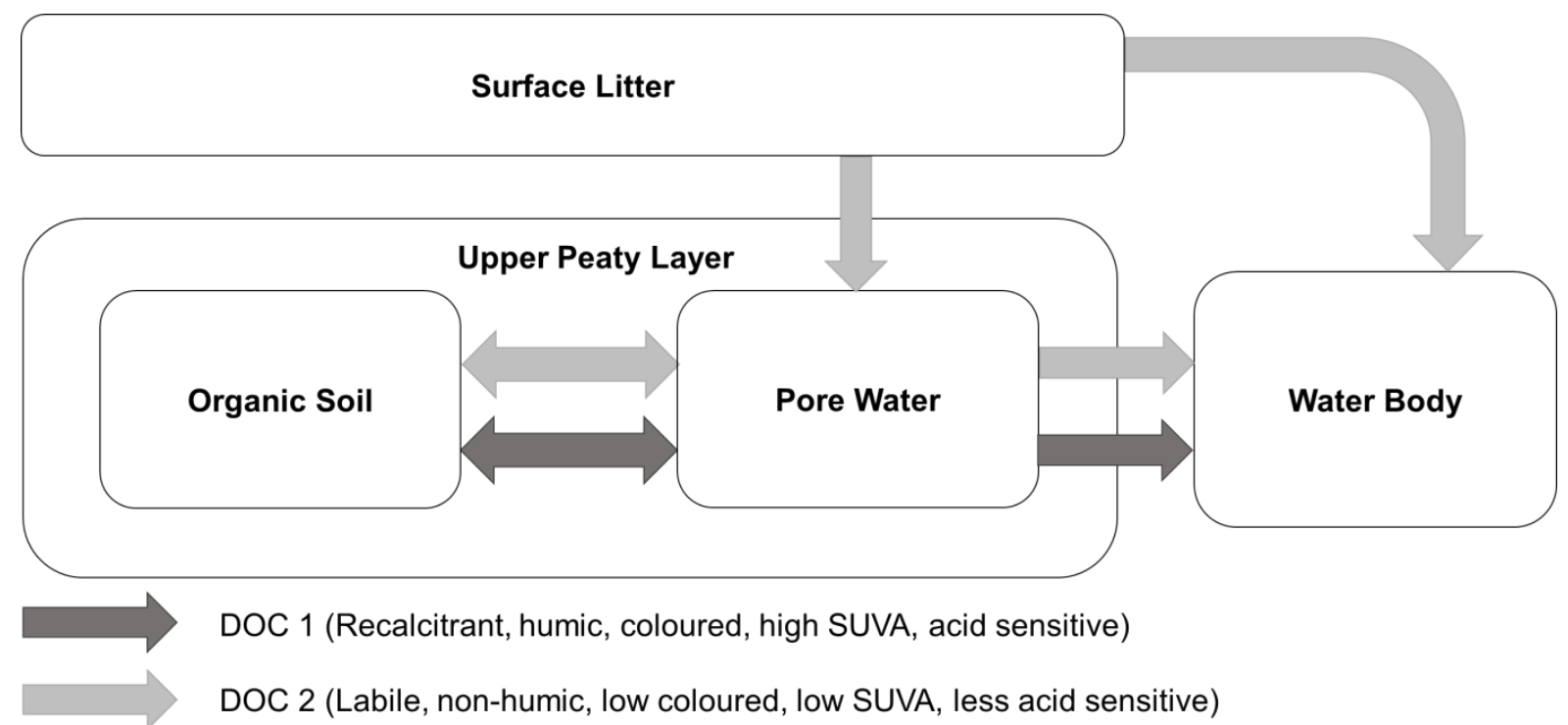

Figure 5: Theoretical pathway model showing the movement of DOM through the different components of the upper surface layer of peat into terrestrial waters.

Aboveground exudates and freshly senesced litter are added to the soil surface, where biological decomposition processes are initiated. A part of the soluble fraction may be transported to waters directly through overland flow (Clark et al., 2007). Since litter DOC production is biologically mediated, and we did not find clear relationships between DOC and $\mathrm{pH}$ in litter extracts indicating that $\mathrm{DOC}$ released from litter was less sensitivity to acidity, the export of DOC to surface waters via this pathway may be largely independent of soil acidity changes. The remaining partly decomposed litter material may enter the surface organic soil below, in either dissolved or solid form, along with direct inputs from root turnover and exudates. In the organic soil, labile organic material is continuously 
decomposed and altered by microbial processes, leading to an accumulation of recalcitrant, high molecular weight organic matter (Malik and Gleixner, 2013). DOM produced from this pool will tend to be more aromatic, as shown by higher SUVA 254 concentrations in our organic soil extracts. The mobilisation of this organic matter from organic soils depends on the biological production of potentially mobile organic matter, and its subsequent dissolution, diffusion and transport into larger soil pores. Our data, showing a very strong relationship between pore water $\mathrm{DOC}$ and $\mathrm{pH}$, suggest that this process of mobilisation from soils to waters is primarily a function of solubility controls related to soil water acidity.

\subsection{Conclusion}

Results from this study indicate that litter is a greater source of DOC, which is less aromatic (as indicated by SUVA 254 ), whilst organic soils produced less DOC which is more aromatic. The acid sensitive fraction of DOC is likely transported through leaching from the upper organic soil layer and not the litter layer. These results suggest it is highly likely that increased solubility of DOC in pore water is due to recovery from acidification. We found little evidence for impact of changes in acidity on DOC production in the litter layer, whilst organic soil DOC concentrations were more strongly related to experimentally manipulated $\mathrm{pH}$, implying that the mobility of this $\mathrm{DOC}$ is subject to physicochemical rather than biotic controls. Therefore we suggest that the increasing DOC trend is due to an increase in export from organic soil rather than increased decomposition and DOC production. Further work is needed to assess the impact of DOC production with recovery from acidification on DOC release from these sources based on longer term monitoring and greater sampling size.

\section{Acknowledgements}

Funding: This work was supported by NERC; the University of Reading, Faculty of Science Studentship; and the Centre for Ecology and Hydrology.

The authors would like to thank Tim Jones and the School of Natural Sciences, Bangor University, for support and the use of laboratory equipment.

\section{References}

Aitkenhead JA, Hope D, Billett MF. The relationship between dissolved organic carbon in stream water and soil organic carbon pools at different spatial scales. Hydrological Processes 1999; 13: 1289-1302. 
Billett MF, Deacon CM, Palmer SM, Dawson JJC, Hope D. Connecting organic carbon in stream water and soils in a peatland catchment. Journal of Geophysical Research: Biogeosciences 2006; 111: G02010.

Billett MF, Palmer SM, Hope D, Deacon C, Storeton-West R, Hargreaves KJ, et al. Linking land-atmosphere-stream carbon fluxes in a lowland peatland system. Global Biogeochemical Cycles 2004; 18: GB1024.

Bragee $P$, Mazier F, Nielsen AB, Rosén P, Fredh D, Brostrom A, et al. Historical TOC concentration minima during peak sulfur deposition in two Swedish lakes. Biogeosciences 2015; 12: 307-322.

Chowdhury S. Trihalomethanes in drinking water: effect of natural organic matter distribution. Water SA 2013; 39: 1-7.

Christ MJ, David MB. Temperature and moisture effects on the production of dissolved organic carbon in a Spodosol. Soil Biology and Biochemistry 1996; 28: 1191-1199.

Clark JM, Ashley D, Wagner M, Chapman PJ, Lane SN, Evans CD, et al. Increased temperature sensitivity of net DOC production from ombrotrophic peat due to water table drawdown. Global Change Biology 2009; 15: 794-807.

Clark JM, Bottrell SH, Evans CD, Monteith DT, Bartlett R, Rose R, et al. The importance of the relationship between scale and process in understanding long-term DOC dynamics. Science of The Total Environment 2010; 408: 2768-2775.

Clark JM, Chapman PJ, Adamson JK, Lane Stuart N. Influence of drought-induced acidification on the mobility of dissolved organic carbon in peat soils. Global Change Biology 2005; 11: 791-809.

Clark JM, Lane SN, Chapman PJ, Adamson JK. Export of dissolved organic carbon from an upland peatland during storm events: Implications for flux estimates. Journal of Hydrology 2007; 347: 438-447.

Clark JM, Lane SN, Chapman PJ, Adamson JK. Link between DOC in near surface peat and stream water in an upland catchment. Science of The Total Environment 2008; 404: 308-315.

Clark JM, Van Der Heijden GMF, Palmer SM, Chapman PJ, Bottrell SH. Variation in the sensitivity of DOC release between different organic soils following $\mathrm{H} 2 \mathrm{SO} 4$ and seasalt additions. European Journal of Soil Science 2011; 62: 267-284.

Couture S, Houle D, Gagnon C. Increases of dissolved organic carbon in temperate and boreal lakes in Quebec, Canada. Environmental Science and Pollution Research 2012; 19: 361-371.

Daniels SM, Evans MG, Agnew CT, Allott TEH. Sulphur leaching from headwater catchments in an eroded peatland, South Pennines, U.K. Science of The Total Environment 2008; 407: 481-496.

de Wit HA, Mulder J, Hindar A, Hole L. Long-Term Increase in Dissolved Organic Carbon in Streamwaters in Norway Is Response to Reduced Acid Deposition. Environmental Science \& Technology 2007; 41: 7706-7713.

Dinsmore KJ, Billett MF, Skiba UM, Rees RM, Drewer J, Helfter C. Role of the aquatic pathway in the carbon and greenhouse gas budgets of a peatland catchment. Global Change Biology 2010; 16: 2750-2762.

Don A, Kalbitz K. Amounts and degradability of dissolved organic carbon from foliar litter at different decomposition stages. Soil Biology and Biochemistry 2005; 37: 2171-2179. 
Ekström SM, Kritzberg ES, Kleja DB, Larsson N, Nilsson PA, Graneli W, et al. Effect of Acid Deposition on Quantity and Quality of Dissolved Organic Matter in Soil-Water. Environmental Science \&amp; Technology 2011; 45: 4733-4739.

Evans CD, Chapman PJ, Clark JM, Monteith DT, Cresser MS. Alternative explanations for rising dissolved organic carbon export from organic soils. Global Change Biology 2006; 12: 2044-2053.

Evans CD, Freeman C, Cork LG, Thomas DN, Reynolds B, Billett MF, et al. Evidence against recent climate-induced destabilisation of soil carbon from $14 \mathrm{C}$ analysis of riverine dissolved organic matter. Geophysical Research Letters 2007; 34: L07407.

Evans CD, Goodale CL, Caporn SJM, Dise NB, Emmett BA, Fernandez IJ, et al. Does elevated nitrogen deposition or ecosystem recovery from acidification drive increased dissolved organic carbon loss from upland soil? A review of evidence from field nitrogen addition experiments. Biogeochemistry 2008; 91: 13-35.

Evans CD, Jones TG, Burden A, Ostle N, Zieliński P, Cooper MDA, et al. Acidity controls on dissolved organic carbon mobility in organic soils. Global Change Biology 2012; 18: 3317-3331.

Evans CD, Monteith DT, Cooper DM. Long-term increases in surface water dissolved organic carbon: Observations, possible causes and environmental impacts. Environmental Pollution 2005; 137: 55-71.

FAO. World reference base for soil resources 2014. International soil classification system for naming soils and creating legends for soil maps 2014.

Freeman C, Evans CD, Monteith DT, Reynolds B, Fenner N. Export of organic carbon from peat soils. Nature 2001; 412: 785-785.

Freeman C, Fenner N, Ostle NJ, Kang H, Dowrick DJ, Reynolds B, et al. Export of dissolved organic carbon from peatlands under elevated carbon dioxide levels. Nature 2004; 430: 195-198.

Ghani A, Dexter M, Perrott KW. Hot-water extractable carbon in soils: a sensitive measurement for determining impacts of fertilisation, grazing and cultivation. Soil Biology and Biochemistry 2003; 35: 1231-1243.

Gorham E. Northern Peatlands: Role in the Carbon Cycle and Probable Responses to Climatic Warming. Ecological Applications 1991; 1: 182-195.

Grieve IC. Variations in chemical composition of the soil solution over a four-year period at an upland site in southwest Scotland. Geoderma 1990; 46: 351-362.

Haitzer M, Höss S, Traunspurger W, Steinberg C. Effects of dissolved organic matter (DOM) on the bioconcentration of organic chemicals in aquatic organisms: A review. Chemosphere 1998; 37: 1335-1362.

Hongve D, Riise G, Kristiansen JF. Increased colour and organic acid concentrations in Norwegian forest lakes and drinking water-a result of increased precipitation? Aquatic sciences 2004; 66: 231-238.

Hood E, Gooseff MN, Johnson SL. Changes in the character of stream water dissolved organic carbon during flushing in three small watersheds, Oregon. Journal of Geophysical Research: Biogeosciences 2006; 111.

Hope D, Billett MF, Cresser MS. A review of the export of carbon in river water: Fluxes and processes. Environmental Pollution 1994; 84: 301-324.

Kalbitz K, Schmerwitz J, Schwesig D, Matzner E. Biodegradation of soil-derived dissolved organic matter as related to its properties. Geoderma 2003; 113: 273-291. 
Kang $\mathrm{H}$, Kwon MJ, Kim S, Lee S, Jones TG, Johncock AC, et al. Biologically driven DOC release from peatlands during recovery from acidification. Nature Communications 2018; 9 : 3807.

Lawlor AJ, Tipping E. Metals in bulk deposition and surface waters at two upland locations in northern England. Environ Pollut 2003; 121: 153-67.

Malik A, Gleixner G. Importance of microbial soil organic matter processing in dissolved organic carbon production. FEMS microbiology ecology 2013; 86: 139-148.

Mastný J, Kaštovská E, Bárta J, Chroňáková A, Borovec J, Šantrůčková H, et al. Quality of DOC produced during litter decomposition of peatland plant dominants. Soil Biology and Biochemistry 2018; 121: 221-230.

McDowell WH, Zsolnay A, Aitkenhead-Peterson JA, Gregorich E, Jones DL, Jödemann D, et al. A comparison of methods to determine the biodegradable dissolved organic carbon from different terrestrial sources. Soil Biology and Biochemistry 2006; 38: 19331942.

Moldan F, Hruška J, Evans CD, Hauhs M. Experimental simulation of the effects of extreme climatic events on major ions, acidity and dissolved organic carbon leaching from a forested catchment, Gårdsjön, Sweden. Biogeochemistry 2012; 107: 455-469.

Monteith DT, Stoddard JL, Evans CD, de Wit HA, Forsius M, Hogasen T, et al. Dissolved organic carbon trends resulting from changes in atmospheric deposition chemistry. Nature 2007; 450: 537-540.

Oulehle F, Chuman T, Hruška J, Krám P, McDowell WH, Myška O, et al. Recovery from acidification alters concentrations and fluxes of solutes from Czech catchments. Biogeochemistry 2017; 132: 251-272.

Oulehle F, Evans CD, Hofmeister J, Krejci R, Tahovska K, Persson T, et al. Major changes in forest carbon and nitrogen cycling caused by declining sulphur deposition. Global Change Biology 2011; 17: 3115-3129.

Oulehle F, Hruška J. Rising trends of dissolved organic matter in drinking-water reservoirs as a result of recovery from acidification in the Ore Mts., Czech Republic. Environmental Pollution 2009; 157: 3433-3439.

Oulehle F, Jones TG, Burden A, Cooper MDA, Lebron I, Zieliński P, et al. Soil-solution partitioning of DOC in acid organic soils: results from a UK field acidification and alkalization experiment. European Journal of Soil Science 2013; 64: 787-796.

Palmer SM, Clark JM, Chapman PJ, van der Heijden GMF, Bottrell SH. Effects of acid sulphate on DOC release in mineral soils: the influence of SO42- retention and Al release. European Journal of Soil Science 2013; 64: 537-544.

Palmer SM, Hope D, Billett MF, Dawson JJC, Bryant CL. Sources of organic and inorganic carbon in a headwater stream: Evidence from carbon isotope studies. Biogeochemistry 2001; 52: 321-338.

Pschenyckyj CM. The effects of acidity on recent changes in carbon cycling in organic soils. Geography and Environmental Science. Ph.D. University of Reading, 2018.

Raymond PA, McClelland JW, Holmes RM, Zhulidov AV, Mull K, Peterson BJ, et al. Flux and age of dissolved organic carbon exported to the Arctic Ocean: A carbon isotopic study of the five largest arctic rivers. Global Biogeochemical Cycles 2007; 21.

Raymond PA, Saiers JE. Event controlled DOC export from forested watersheds. Biogeochemistry 2010; 100: 197-209.

RDevelopment Core Team R. R: A language and environment for statistical computing. $R$ foundation for statistical computing Vienna, Austria, 2008. 
Ritson JP, Bell M, Brazier RE, Grand-Clement E, Graham NJD, Freeman C, et al. Managing peatland vegetation for drinking water treatment. Scientific Reports 2016; 6: 9.

Ritson JP, Bell M, Graham NJD, Templeton MR, Brazier RE, Verhoef A, et al. Simulated climate change impact on summer dissolved organic carbon release from peat and surface vegetation: Implications for drinking water treatment. Water Research 2014; 67: 66-76.

Ritson JP, Brazier RE, Graham NJD, Freeman C, Templeton MR, Clark JM. The effect of drought on dissolved organic carbon (DOC) release from peatland soil and vegetation sources. Biogeosciences 2017; 14: 2891-2902.

Saadi I, Borisover M, Armon R, Laor Y. Monitoring of effluent DOM biodegradation using fluorescence, UV and DOC measurements. Chemosphere 2006; 63: 530-539.

SanClements MD, Oelsner GP, McKnight DM, Stoddard JL, Nelson SJ. New Insights into the Source of Decadal Increases of Dissolved Organic Matter in Acid-Sensitive Lakes of the Northeastern United States. Environmental Science \&amp;amp; Technology 2012a; 46: 3212-3219.

SanClements MD, Oelsner GP, McKnight DM, Stoddard JL, Nelson SJ. New Insights into the Source of Decadal Increases of Dissolved Organic Matter in Acid-Sensitive Lakes of the Northeastern United States. Environmental Science \&amp;amp;amp; Technology 2012b; 46: 3212-3219.

Schindler DW. Light, Temperature, and Oxygen Regimes of Selected Lakes in the Experimental Lakes Area, Northwestern Ontario. Journal of the Fisheries Research Board of Canada 1971; 28: 157-169.

Spencer RGM, Butler KD, Aiken GR. Dissolved organic carbon and chromophoric dissolved organic matter properties of rivers in the USA. Journal of Geophysical Research: Biogeosciences 2012; 117.

Tallis JH. Mass Movement and Erosion of a Southern Pennine Blanket Peat. Journal of Ecology 1985; 73: 283-315.

Tipping E, Billett MF, Bryant CL, Buckingham S, Thacker SA. Sources and ages of dissolved organic matter in peatland streams: evidence from chemistry mixture modelling and radiocarbon data. Biogeochemistry 2010; 100: 121-137.

Tipping E, Hilton J, James B. Dissolved organic matter in Cumbrian lakes and streams. Freshwater Biology 1988; 19: 371-378.

Weishaar JL, Aiken GR, Bergamaschi BA, Fram MS, Fujii R, Mopper K. Evaluation of Specific Ultraviolet Absorbance as an Indicator of the Chemical Composition and Reactivity of Dissolved Organic Carbon. Environmental Science \& Technology 2003; 37: 47024708.

Wetzel RG. Gradient-dominated ecosystems: sources and regulatory functions of dissolved organic matter in freshwater ecosystems. Hydrobiologia 1992; 229: 181-198.

Worrall F, Burt T, Shedden R. Long term records of riverine dissolved organic matter. Biogeochemistry 2003; 64: 165-178. 